\title{
BRISC and BRCA1-A Complex Member 2
}

National Cancer Institute

\section{Source}

National Cancer Institute. BRISC and BRCA1-A Complex Member 2. NCI Thesaurus. Code C124107.

BRISC and BRCA1-A complex member 2 (383 aa, $43 \mathrm{kDa}$ ) is encoded by the human BABAM2 gene. This protein is involved in binding to ubiquitinated histones. 